2019 (112): 153-164.

(C) A szerző(k) 2019

replika.hu/replika/112

\title{
Havas Ádám
}

\section{„A radıkálıs kritılia soha nem a centrum felöl érkezılk" \\ Interjú Bruce Johnsonnal}

\section{Szerkesztői előszó}

2017-ben kerültem kapcsolatba Johnson professzorral az IASPM ${ }^{1}$ levelezési listáján keresztül, válaszul arra a felajánlására, hogy ingyenes példányokat küld The Inaudible Music: Jazz, Gender and Australian Modernity ${ }^{2}$ (A hallhatatlan zene: jazz, gender és ausztrál modernitás) címü könyvéből, miután észrevette, hogy az Amazon.com-on kapható utolsó példány 997 fontba kerül. Akkoriban épp a disszertációm megírásához kerestem anyagokat az Európán kívüli jazz kialakulásáról, így boldogan éltem a recenzióírás lehetőségével, főleg, miután rájöttem, hogy Johnson könyvének számos gondolata párhuzamba állítható a magyar jazz fejlődéstörténetével a két ország közötti jelentős történeti-kulturális különbségek ellenére is.

Noha a most közölt interjú alapötletét az egyre népszerübb diaszporikus jazzkutatással [diasporic jazz studies - H. Á.] ${ }^{3}$ kapcsolatos kérdések motiválták, a beszélgetés során a populáriszene-kutatás és jazztanulmányok megismerési pozíciójával összefüggésben is számos témát érintettünk. Ezért az interjúkérdések összeállításánál igyekeztem eme angolszász tudo-

Forrás: első közlés. Hungarian translation @ Replika. Az itt közölt interjút 2019. október 16-án rögzítettem - H. Á.

1 International Association for the Study of Popular Music (a fordító megjegyzése).

2 Johnson, Bruce (2000): The Inaudible Music: Jazz, Gender and Australian Modernity. Sydney: Currency Press.

3 A továbbiakban a szerkesztői megjegyzések kapcsos zárójelben szerepelnek - H. Á. 
mányos életben jelentős hagyományokkal bíró diszciplínák olyan kortárs relevanciával bíró kihívásait bemutatni, melyek a nem „bennfentes” olvasóközönség számára is izgalmasak, inspirálók lehetnek. Ilyen kérdésfelvetések közé tartoznak például a populáris zene és a jazz közötti kapcsolódások problematikája, a populáris zene és a kulturális globalizáció összefüggései, továbbá a tudományos világban jelen lévő centrum-periféria pozíciókkal kapcsolatos hatalmi különbségek értelmezési lehetőségei, különös tekintettel az Észak-Amerikán kívüli diaszporikus jazz kutatására.

Az elmúlt két évtizedben Johnson e tárgykörökben írt tanulmányai rendkívül jelentősnek mondhatók, ő maga több nemzetközi egyetem vendégprofesszora és oktatója, emellett aktív jazztrombitás is: zenei közremüködései nagyjából 20 - Ausztráliában és Európában rögzített albumon hallhatók. A vele készült interjú a Zipernovszky Kornéllal közösen szerkesztett Jazztanulmányok címet viselő tematikus lapszám (Replika 101-102) koncepciójához is szervesen kapcsolódik. Végül, az interjú magyar nyelvü közlése reményeim szerint a tudományterület további népszerüsítéséhez járul hozzá.

Havas Ádám

Budapest, 2019. november 19.

Havas Ádám: El tudnád mondani, hogyan válik egy angol irodalommal foglalkozó professzor a populáris zene kutatójává?

Bruce Johnson: Főként azért próbáltam meg elkülöníteni ezt a két szerepet egymástól, mert részint nem akartam, hogy a diákjaim velem jöjjenek a kocsmába, ahol zenéltem, és ahol olyan jól éreztem magam... [nevet] Azután az Oxford University Press megbízott a The Oxford Companion to Australian Jazz ${ }^{4}$ [Az ausztrál jazz oxfordi kézikönyve] címü munka megírásával, ami ennek a két útnak a kereszteződését jelentette. Amikor elkészültem a könyvvel, a kar felelős dékánja azt kérdezte tőlem: „Miért nem tartasz néhány kurzust ebben a tárgyban?” - tehát a kutatási irányok így közelítettek egymáshoz. Azonban volt még egy párhuzam is: akkoriban az Erzsébet-kori irodalomra specializálódtam, és egyre inkább felfigyeltem arra a tényre, hogy amit ma irodalomként olvasunk, az az Erzsébet-kori ember számára gyakran szájhagyomány útján vált ismertté. Tehát Shakespeare-t nem irodalomként olvasták, hanem mint drámaírót, Sidney Arcadiáját például hangosan felolvasták, nem is nyomtatták ki, úgyhogy elkezdtem azon gondolkodni, hogy hogyan hangozhattak ezek az alkotások: mi a különbség aközött, hogy olvasunk valamit és hallunk valamit, és hogyan közvetíti a fülünk a jelentéseket... Szóval ez a két út tovább közelített egymáshoz és arra ösztönzött, hogy zenét, illetve populáris zenét kutassak, valamint mostanság általánosságban a hangot és a hang fiziológiáját tanulmányozzam.

H. Á. Tehát ez lett a fö akadémiai profilod, vagy a jazzel kapcsolatos tudományos törekvéseiddel párhuzamosan ugyanígy tanítottál irodalmat is?

B. J. Az egyetemről 2005-ben korán nyugdíjba mentem, és ekkoriban a 16. századtól a 20. századig terjedő angol irodalmi kurzusokat tartottam, de ugyanígy tartottam órákat a

4 Johnson, Bruce (1988): The Oxford Companion to Australian Jazz. Oxford: Oxford University Press. 
jazz történetéről, mint ahogy számos anyagot oktattam a zenei hangzásról is. Ezután otthagytam ezt az állást, és vendégprofesszorként tanítottam kultúrtörténetet Turkuban, majd Glasgow-ban és Ausztráliában, ahol aztán ismét zenét oktattam.

H. Á. Milyen gyakran játszol jazzt gyakorló zenészként? Ez azért érdekes számomra, mert a The Inaudible Music címü könyved olvasásakor jöttem rá arra, hogy zenészként szerzett tapasztalataid különleges szereppel bírnak a munkádban. De milyen gyakran adódik alkalmad szerepelni és játszani?

B. J. Az amatőr és a professzionális jazz-zenész között az a különbség, hogy az amatőrnek valószínűleg van bevétele [nevet], de nem minden esetben fizetnek a játékáért. Jazzegyüttessel egy héten legalább kétszer, talán háromszor is játszottam a(z) [ausztráliai] Blue Montainsban található lakóhelyemen. Mindezt persze az élvezet kedvéért, de azért néhány koncertet ezek közül azért meg is fizettek. A múlt hétvégén péntek éjjel adtam koncertet, tegnap próbaworkshopon vettem részt, holnaptól egy dél-ausztráliai fesztiválra megyek. Tulajdonképpen sokat játszom, de emiatt nem feltétlenül kapok honoráriumot [nevet]. ${ }^{5}$

H. Á. Egyértelmüen kiolvasható a müveidből, hogy valóban elkötelezett vagy a zene „belülről”, a jazz-zenész nézőpontjából történő bemutatásában, ami ugyanakkor szemben áll a zenetudományi elemzés "textuális” fókuszával. Szerinted ez a nézőpont azok számára is hozzáférheto, akik nem zenélnek?

B. J. Az egyik oka annak, amiért elkezdtem rendszeresen írni a jazzről, hogy magam is olvastam jazzelőadásokról és jazzfelvételekről írt recenziókat, zenészként pedig többször arra a következtetésre jutottam, hogy [amit játszom] nem olyan, mint amilyennek leírják. Sok-sok évvel ezelött olvastam egy koncertemröl írt recenziót, és azt gondoltam: „Nem értem, miröl beszélnek”: [a kommentátor] „heroikus koncepciókról” beszélt, de egyáltalán nincs semmiféle heroikus abban, amit csinálok, ez egyszerüen nem ilyen... Így arra jutottam, hogy talán el kellene kezdenem arról írni, milyen érzés jazzt játszani. Az egyik legelső cikkem, amiben pontosan erről írtam, a Helmi Järviluoma szerkesztette Soundscapes: Essays on Vroom and $M o o^{6}$ [Zenei tájak: Esszék Vroomról és Mooról] című gyüjteményes kötetben jelent meg. Valójában meg kell vallanom: éppen ittam [nevet], elkezdtem írni, majd egy fejezet kerekedett ki belőle, ami tényleg arról szól, hogy miért zenélek és milyen érzés, amikor jazzt játszik az ember. Tehát ebben segít, ha zenész vagy: a zenének ez egyfajta fenomenológiai olvasatát kínálja.

\section{H. Á. Szerinted laikusok is képesek írni abból a fenomenológiai nézőpontból, amit javasolsz?}

B. J. Azt gondolom, hogy hatalmas különbség van aközött, hogy valaki játszik hangszeren - és én az éneklést is beleszámítom a hangszeren játszás fogalmába -, vagy épp semmilyen hangszeren nem játszik, mindegy, hogy milyen rosszul is zenél. Természetesen azoknak is van mondanivalójuk a zenéről, akik nem zenélnek, de bárki, aki szerepelt már a szín-

$5 \mathrm{Az}$ angolban ez a mondat a „playing” és „paying” igék kiejtésbeli és külalaki hasonlóságára, ill. jelentésbeli különbségére épül (a fordító megjegyzése).

6 Järviluoma, Helmi és Bruce Johnson (szerk.) (1994): Soundscapes: Essays on Vroom and Moo. Tampere: University of Tampere, Dept. of Folk Tradition, Institute of Rhythm Music. 
padon emberek előtt és megpróbált hangszeren játszani, legyen az blues, jazz vagy bármi más, rendelkezik egy olyan sajátos tudással, ami egy laikus számára nem hozzáférhető. Nem azt mondom, hogy a két dolog minőségileg különböző, csupán azt, hogy ez lehetővé tesz egy sajátos fenomenológiai megértést, amit viszont azok nem tapasztalnak meg, akik nem zenélnek.

H. Á. A jazz nagyon sajátosan kapcsolódik a populáris zenéhez. Hogyan értelmezed jelenleg ezt a komplex viszonyt?

B. J. Számomra először is a populáris szó történelmileg nagyon specifikus kifejezés, vagyis körültekintően kell használnunk. Ha a populáris szó jelent bármit is, akkor számomra a jazzt is magában foglalja. Két okra vezethető vissza, hogy a jazz miért tart a marginalizálódás irányába a populáris zenében: a jazzrajongók a rock’n'rollt a zene egy vulgáris fajtájával azonosították, majd ezáltal tudatosan elhatárolódtak a rocktól. A populáriszene-kutatás nagyjából ugyanakkortól datálható, mint a rock vagy a késői rock és pop térnyerése. Ennélfogva a populáriszene-kutatást egyre inkább a rock and rollal hozták összefüggésbe; ma már ott tartunk, hogy amikor valaki popot mond, gyakran a populáris zenére gondol és vice versa. Éppen ezért nem gondolom, hogy túlságosan hasznos lenne az, ha egyenlőségjelet tennénk a kettő közé. Számos okból kifolyólag azt mondhatjuk, hogy egyfelöl a jazz volt az első olyan új populáris zene a 20. században, amit a korabeli kortárs technológia lemezfelvételeken rögzített, majd forgalomba hozott, és mint olyan, roppant hasznos tanulságokkal szolgálhat a populáris zene későbbi fejlödésére nézve, például a rock tekintetében is. A rock/pop történetének és jövőjének megítéléséhez vessünk egy pillantást a jazzre, ami egy jó kiindulópont... Nem értek egyet azzal a felfogással, miszerint a popzene és a populáris zene megegyeznének egymással: a pop a populáris zene egyik formája, mint ahogy a jazz is.

H. Á. Visszatérve az Európában és Ausztráliában szerzett oktatói tapasztalataidhoz, nemcsak azzal kapcsolatban rendelkezel sajátos szakértelemmel, hogy a jazzt hogyan játsszák különbözö, egymástól távoli helyeken, hanem azzal kapcsolatban is, hogy a jazzt és a populáris zenét hogyan kutatják különféle kulturális kontextusokban. A kérdés adja magát: mik a hasonlóságok és mik a különbségek a populáriszene-kutatásban Ausztrália és Európa esetében?

B. J. Vannak nyilvánvaló hasonlóságok: azok az emberek, akik populáris zenét tanulnak Ausztráliában, nagyjából ugyanazt tanulják, mint akik bárhol másutt folytatnak ilyen jellegü tanulmányokat. A tanulmányokat keretezö attitüdöket viszont eltérőnek találom: Európa néhány részén, kifejezetten a számomra figyelemre méltó északi régióban - és ez összefügg a saját karrierem során tapasztaltakkal - a populáriszene-kutatás számos értelemben jóval szélesebb horizonttal rendelkezik, a szó stilisztikai és diszciplináris értelmében egyaránt. Amikor Finnországban kezdtem el dolgozni, az egyik szembeötlö dolog az volt, hogy soha nem hallottam, hogy a finnek egy zenét visszautasítottak volna elcsépeltnek minősítve azt, mintha számukra nem létezne „elcsépelt”, vagy idejétmúlt zene. Az egyik legnagyobb hatást a korábban említett Helmi Järviluoma tette rám, aki pelimannit ${ }^{7}$ zenét tanult. Nos, nem tudom elképzelni azt, hogy egy ausztrál a pelimannittal egyenértékű zenét tanuljon, mert ez

7 Vonóshangszerekre épülő hagyományos finn tánczene - H. Á. 
Ausztráliában inkább öregemberek régimódi zenéjének számítana. Akik Ausztráliában tanulnak populáris zenét, a müfaj kapcsán általában valami groove-os hangzásra asszociálnak, vagyis a fiatalok popzenéjét értik alatta.

A másik dolog, és ez nagyon fontos, amire az északi régió legtöbb helyén, különösen Finnországban lettem figyelmes, az az, hogy a finnek normális emberekként tekintenek a zenészekre. Amikor először voltam Finnországban, azt kérdezték tőlem: „Ki vagy? Mit csinálsz?” - és én általánosságban azt feleltem: „Zenész vagyok”; erre úgy néztek rám, mintha azt mondtam volna: „és lélegzem” - hát persze hogy zenész vagy, majdnem mindenki zenész, ez teljesen normális... Ezzel szemben az általam leginkább ismert Ausztráliában, és minden bizonnyal az angolszász világban, zenésznek lenni egyet jelent azzal, hogy más vagy, hogy különleges vagy. Én ezt a látásmódot ellenszenvesnek találom. Úgy gondolom, sokkal civilizáltabb a zenészeket normális embereknek tekinteni. Egy olyasfajta gondolat ez, amivel sokkal többször találkozni az északi régióban, mint az angolszász országokban.

H. Á. A zenésznek ez a romanticizált eszméje kulturálisan és történelmileg kódolt, amint ezt a populáris zene fogalmával kapcsolatban az imént te is hangsúlyoztad. Ennek a képzete azzal is összekapcsolódik, hogy a jazztanulmányok müvelöi évtizedeken keresztül elkötelezett hívei voltak az ún. „nagy egyéniségek kánonján” alapuló diakrón historiográfiai hagyománynak. Tudod, például a Miles Davis vagy Charlie Parker életéről készült monográfiák... Összefüggésbe hozható-e mindez a populáriszene-tanulmányok tudományfelfogásával?

B. J. Igen, és ez összefügg a nagy történelmi személyiségek képzetével és a jazztörténet kanonikus megközelítésmódjával. Mert miről is szól a jazztörténet? Valóban kivételes emberekről! [Szerintem] nem, nem róluk szól! A jazztörténet mindenkiröl szól, aki zenél és jazzt játszik, legalábbis elgondolásom szerint. Zenei konferenciákon már többször is javasoltam, hogy olyan témát kellene választanunk, ami alapján mindenkinek egy olyan zenészről kellene írnia, akinek a hallgatása számára kínos lenne. Így arra lennénk kényszerítve, hogy leüljünk és átgondoljuk: „Miért olyan igazán népszerü az adott zenész? Mi történik? Mi a pozitívum?”, ahelyett, hogy azt mondanánk: „Ugyan, ki fog előadást tartani Julio Iglesiasról?” Nos, tényleg szívesen olvasnék egy cikket arról, miért volt Julio Iglesias olyan népszerü... [nevet]

H. Á. The Inaudible Music címü könyvedet egy Abe Romainnek ${ }^{8}$ szentelt fejezettel kezded, ami eszembe juttatta azt a feladatot, amire vállalkoztál: a könyv valamiképpen tartalmazza azon zenészek rejtett történetének feltárását, akik nincsenek benne a „nagy emberek kánonjában”.

B. J. Teljesen egyetértek. Amikor viszont Abe Romainról írtam, valami olyasmit is megtanultam a korai 20. századi zenecsinálás módjáról, amit korábban soha nem ismertem. Megtanultam valamit arról, hogyan társítsam a színpadi müsor bizonyos fajtáit egymással. A zenészeknek ugyanis olyan kifutópályát kínáltak fel, ahol csak körbe-körbe jártak a nekik kiosztott instrukciókkal. Ezt persze nem találtam volna ki magamtól, ha ausztrál jazztanulmányaim során kizárólag lemezeket hallgatok. Annyi zenésszel kell beszélned, amennyivel csak lehetséges, hogy felfedezd, milyenek voltak a körülményeik, amelyek között dolgozniuk kellett, különösen utazó zenészekkel, tudod, hétköznapi dolgozó zenészekkel.

8 A korai ausztrál jazz egyik alapító atyja - H. Á. 
H. Á. Pontosan emiatt készitek állandóan interjúkat... A kutatásod különféle diszciplinákra és módszerekre épül, beleértve a kritikai kultúratudományt, szociológiát, etnográfiát, ami lényegét tekintve egyfajta hibrid megközelitésmódot feltételez. A 2002-ben kiadott Cambridge Companion to Jazz Studies kötetben megjelent "Jazz as a Cultural Practice" [A jazz mint kulturális gyakorlat] címủ írásod azért is volt rám nagy hatással, mert abban a hangsúlyt a zenetanulásról egyértelmüen a kulturalista megközelítésre helyezted, ami szemben áll a zenetudományban domináns szövegközpontú megközelítésekkel. Ez az, ami alapján szociológusként azt mondhatom, hogy a különbözö diszciplínák meglehetösen merev szétválasztása ellenére a populáriszene-tanulmányok, a jazztanulmányok vagy épp a kultúraszociológia számos esetben ugyanarról a jelenségröl beszélnek.

B. J. Egyetértek, és azt gondolom, hogy a diszciplináris korlátok lebontása alapvető fontossággal bír, mielött bármiféle paradigmaváltásról beszélhetünk a populáris zenében.

\section{H. Á. A populáris zenei tanulmányokban mi a „paradigmaváltásról” alkotott víziód?}

B. J. A magam részéről az egyik legfontosabb váltás a zene zeneként való értelmezésétől a zenét elsődlegesen hangként [sound] értelmező megközelítés felé való elmozdulás volt. Hangként abban az értelemben, ami lehetővé teszi, hogy bioakusztikáról, a hallás fiziológiájáról, hogy szonikus jelentéskonstrukciók mikéntjéről beszéljünk. Nálam ez hatalmas horizontot nyitott meg, melynek felderítésével valószínüleg két évtizede foglalkozom már, úgyhogy számomra ez volt a paradigmaváltás: nem zene, hanem hang!

\section{H. Á. Ami döntö különbségtétel. Akkor tehát ez lenne a zene fenomenológiai megközelítése?}

B. J. Inkább fenomenológiai megközelítés, mint esztétikai. De azt is gondolom, hogy ha a zenei jelentéskonstrukciók területére merészkedünk, úgy az rendkívül sokat elárul esztétikai kérdésekről is. Addig nem tudod érdemben feltárni az esztétikát, amíg nem mozdulsz ki az esztétika tartományából.

H. Á. Ez az a megközelítés, amit a kultúraszociológusok évtizedek óta képviselnek. A kortárs jazztanulmányok témakörében írt cikkek bibliográfiáit végigpásztázva szociológiai referenciákra lettem figyelmes, különösen a '80-as és a korai '90-es évektöl, amikor Howard Becker (1982) és Pierre Bourdieu (1984; 1993) azóta klasszikussá vált könyveit megjelentették. ${ }^{10}$ A szociológiai referenciák növekvö népszerüségének egyik lehetséges értelmezése talán épp az, hogy az egyes kiválasztott egyének életútjai helyett egyre több figyelem irányul az esztétikai érték kialakulásának társadalmi vonatkozásaira. A társadalomtudományok, illetve a szociológia megítélésem szerint nagyban hozzájárultak ehhez a jazztanulmányokban bekövetkezö „paradigmaváltáshoz".

9 Johnson, Bruce (2002): Jazz as a Cultural Practice. In Cambridge Companion to Jazz Studies. Mervyn Cooke és David Horn (szerk.). Cambridge: Cambridge University Press, 96-113.

10 Bourdieu, Pierre (1984 [1979]): Distinction. A Social Critique of the Judgement of Taste. London: Routledge and Kegan Paul; Bourdieu, Pierre (1993): The Field of Cultural Production. New York: Columbia University Press; Becker, Howard S. (1982): Art Worlds. Oakland: University of California Press. 
B. J. Teljesen egyetértek veled. Szerintem mindaddig, amíg a jazztörténetet uraló történetírás paradigmáján belül mozgunk, egyszerüen nem tudjuk kitágítani a horizontunkat, ehelyett újra meg újra elmondjuk majd ugyanazt a történetet, amíg persze ki nem törünk ebből az Amerika-centrikus skatulyából.

H. Á. A kultúrakutatás kortárs intézményes kerete, ideértve a populáris zenét és a jazzt is, nekem igazán fragmentáltnak tünik, ugyanakkor az általad javasolt megközelítésmód különféle perspektívákat és episztemológiai pozíciókat foglal magában a zene fenomenológiai konstrukciójától kezdve a szonikus és esztétikai tapasztalat tanulmányozásáig. Szintén vitás pontnak látom, hogy a jazzdiaszpórával kapcsolatos szakirodalom burjánzása ellenére a föbb diskurzusokat angolszász hangok formálják. Mit gondolsz erről?

B. J. Egyetértek abban, hogy a jazztanulmányokat angloeurópai hangok uralják, aminek számos oka van. Ha jól értem a kérdést, akkor ahhoz, hogy megértsük a jazz globális történetét, ki kell lépnünk az angloeurópai központú történetírói modellből - számomra ez nyilvánvaló.

H. Á. Hogyan találhatnak értő fülekre ezek a „diaszporikus” hangok, ha a kapuörök majd mindegyike föként jó hírü angolszász és európai affiliációval rendelkezö kutató?

B. J. Amiről beszélsz, az egyszerűen óriási türelmet igényel. Tulajdonképpen erről van szó: elkezdesz valamit csinálni, és azt gondolod: „Nem mintha számítana, hogy két éven belül jutok a végére, talán még tíz éven belül sem, pusztán azért csinálom ezt, mert érdekel." Megítélésem szerint, ami egyben a vezérelvem is: a radikális kritika soha nem a centrum felöl érkezik. A hatalom forrása sokszor egy narratíva életben tartásában rejlik, így ezt a narratívát nem belülről fogja radikális kihívás érni, hanem csakis a szélekről. Tehát, dolgozol csendesen és türelmesen a széleken, és azt gondolod, hogy „egyrészt szeretek itt dolgozni” [nevet], másrészt egy nap talán a felhalmozott munka kritikus tömeget fog képezni a centrum megkérdőjelezéséhez. Szóval csak türelem, türelem, türelem...

H. Á. Nézőpontod szerint a marginális pozíció egyben erőforrás is.

B. J. Így van, teljes mértékben, mivel tudom, hogy fellelhetek valamit a periférián, amit a centrum nem tárna fel számomra.

H. Á. Ugyanakkor, ha a tudományos világban ez idáig marginalizált hangok perspektívájára összpontositasz, a tudománytermelésben egy paradox mozgást figyelhetsz meg, mely során a marginalizált hangok a centrum felé kívánnak elmozdulni.

B. J. Mindig is a szélekhez, a mellözötthöz való újbóli visszanyúlás volt a cél: ha az az érzésem, hogy vizsgálódásaim tárgyát már befogadta a centrum, akkor azt mondom magamban: „Oké, ez lehet a tiétek, én visszamegyek oda, ahonnan jöttem, mert az sokkal szórakoztatóbb.”

H. Á. A The Inaudible Music a 20. század első felét tárgyalja, egészen az '50-es évekig. Miért erre a korszakra, a korai jazz idöszakára esett a választásod? 
B. J. Általában véve sokkal érdekesebbnek találtam a diaszporikus jazz korai napjait, mint mondjuk az 1950-es évek közepét és a '60-as éveket, amikor az amerikai jazzt már meglehetősen nehezen lehetett szétválasztani az Amerikán kívül játszottól. Ezt a zenét kodifikálták és standardizálták; még a lickekről ${ }^{11}$ is szótárak készültek, és így tovább. Míg sokan élvezik ennek a korszaknak a tanulmányozását, engem sokkal jobban érdekelt az, amit akár „rossz zenének" is nevezhetnénk - az a zene érdekelt, ami még mindig a kialakulás folyamatában volt, vagy ahogyan korábban megfogalmaztam: A jazzt nem az USA-ban találták fel, majd exportálták onnan; a jazzt globalizálódásának folyamata során találták fel. A globalizáció eme korai szakasza nagyon érdekes számomra. Igazán érdekesnek találom, ha hallhatok egy eredeti hangon megszólaló és autentikusan játszó jazzegyüttest, amely olyan zenét hoz létre, amit amúgy nem hívnánk jazznek. Szerintem van valami felettébb érdekes az ilyen zene tanulmányozásában.

H. Á. A Jazz Diaspora: Music and Globalism címú új könyved szintén ezt a modellt emeli át, miszerint a jazz az elterjedésének, illetve a globalizálódásának a folyamatában alakult ki, aminek mélyreható következményei vannak az általánosan vett jazztörténetírásban.

\section{B. J. Így van.}

H. Á. Ez a lényege ezeknek az írásoknak, melyek legitimitást biztosítanak a diaszporikus hangoknak, mert nézetem szerint teljességgel újradefiniálják azokat a hierarchikus struktúrákat, melyek kijelölik, hogy mi az, ami érdekes, és mi az, ami nem érdekes a tudományos vizsgálódások számára. Mindez azért is fontos, mert egyben a jazz aktuális gyakorlatairól is szól. Tudnál még egy keveset mondani az új könyvedröl?

B. J. [A könyv] ebből a megfontolásból nőtte ki magát... A Routledge Kiadó felkért egy Egyesült Államokon kívüli diaszporikus jazzről szóló esszé megírására a Companion to Jazz Studies kiadásukhoz. Az Encyclopaedia of the Popular Music of the World ${ }^{12}$ [A világ populáris zenéjének enciklopédiája] pedig az USA-n kívüli jazzről szóló esszé megírására kért fel. A két kutatás előkészítésekor azt gondoltam, hogy tulajdonképpen itt egy könyvről van szó, mivel nem tudom teljesen kifejteni azokat a dolgokat, amelyek még kialakulófélben vannak. Így átnéztem a Routledge-nek írt esszémet, és azt gondoltam, hogy ez egy könyvvé tudna kikerekedni, amit aztán egy javaslat formájában előterjesztettem, amit később el is fogadtak.

\section{H. Á. Elemzéseidben a Finnországban szerzett tapasztalataidat is feldolgozod?}

B. J. Ami azt illeti, igen. Sok időt szenteltem a finn történelem tanulmányozásának, különösen a 20. század elejei finn történelemnek, és számos kollégám van, akiknek hálával tartozom

11 A lick instrumentális frázis a jazzben, ami gitáron, nagybőgőn vagy más dallamhangszeren játszott zenei „szavakat” vagy „mondatokat” jelöl, melyeket többek között az improvizáció szótáraként is alkalmaznak. A lick rövid, akkordváltást nem tartalmazó dallamvonalból épül fel, többnyire egy vagy két ütem hosszúságban (a fordító megjegyzése).

12 Shepherd, John et al. (szerk.) (2014): Encyclopaedia of the Popular Music of the World. London és New York: Bloomsbury. 
azért a sok információért, amit kaptam tölük. Az egyik közülük a finn zenetudós Anu Juva, aki számos felvilágosítással szolgált például arról, hogy hogyan épült fel egy finn tánc. Most persze úgy mondjuk, hogy megyünk táncolni, de a 20. század első felében a jazz és a tánc nem különült el élesen egymástól, tehát a jazz egyben tánc is volt. Ezért feltettem magamnak a kérdést: mi is volt akkor a tánc? Sajátos forgatókönyvet képzelhetünk magunk elé, például, hogy az emberek elegáns öltönyökben táncolnak, vagy talán az a kép tárul elénk, hogy menő srácok szvinget lejtenek a parketten... Ám a tánc egyáltalán nem ilyen volt Finnországban a 20. század elején. Az Anu Juvával és Johannes Brusilával folytatott beszélgetések során kellett rájönnöm arra, hogy a táncként felfogott jazz valami gyökeresen mást jelent különböző helyeken és különböző korokban.

H. Á. Finnországban mennyiben hozható összefüggésbe a korai jazz fejlődése etnikai kérdésekkel vagy osztályproblémákkal?

B. J. Annak függvénye volt, hogy a Vörösök vagy a Fehérek oldalán álltál-e, mert Finnországban később [1918-ban] nagyon komoly lelki keserüséget és fizikai károkat hátrahagyó polgárháború tört ki. A politikához füződő viszonyodtól nagyban függött az, hogy milyen típusú eseményre is mentél, amikor táncolni indultál. Jóformán nincs olyan társadalmi erö, amely ne gyakorolna fontos hatást a szórakozóhelyekre és a szórakozással összefüggő társadalmi gyakorlatokra.

H. Á. Éppen ez az, amiért különösen érdekes egy szociológus számára, hogy a szimbolikus különbségtételek miképpen öltenek testet a jazzel összefüggésbe hozható kulturális gyakorlatokban. A budapesti jazzszcénával kapcsolatos tapasztalataim azt mondatják velem, hogy a kortárs jazz-zenész identitásának lényeges részét képezi, ha a jazzt nem tánczeneként játssza, másképpen fogalmazva: a jazz-zenészek büszkék arra, hogy elhatárolódnak a kommerciális szórakoztatóipartól - vagy ha tetszik, a tánctól.

B. J. A most megjelenö könyvemben a mellett érvelek, hogy a jazztörténet talán legfontosabb fejleménye, átmeneti korszaka, az volt, amikor leválasztotta magát a táncról. ${ }^{13}$ Nagyon nehezen értelmezhető, mit jelentett az embereknek az, amikor azt mondták, hogy „a jazz egy tánc”, ami egy olyan állítás, amit az emberek előszeretettel alkalmaztak, ha a „jazzcsinálásról" beszéltek. A jazz táncként való értelmezése a testről szólt, és persze az történt, hogy a jazzrajongók és -kommentátorok megkísérelték ezt a jazzt müvészetté emelni, ugyanakkor ezzel párhuzamosan igyekeztek megszabadulni a testtöl, ami egy alapvetö váltás volt a zene társadalmi funkciójában és annak értelmezésében.

H. Á. Ez az, amit megtanulhatunk DeVeaux The Birth of the Bebop ${ }^{14}$ [A bebop születése] címü könyvéböl, mivel érinti ezt az elkülönülést. Nagyon érdekes volt látni az USA és Európa közti különbségeket, különös tekintettel az Európában lezajlott „emancipációra”, kiváltképp az államszocialista blokkban, ahogyan a zenész cigányok felhagytak a kávéházakban játszott

13 „Tánc” alatt Johnson minden bizonnyal az 1940-es évek közepéig, azaz a jazz modernista fordulatáig hatalmas népszerüségnek örvendő big band formációk által is szolgáltatott „swinges tánczenét” érti - H. Á.

14 DeVeaux, Scott (1999): The Birth of the Bebop. A Social and Musical History. California: University of California Press. 
tánczenével mint családi tradícióval a fösodorbeli „mainstream jazz” (bebop) kedvéért. Jazz általi emancipációjuk egyik kulcsmomentuma a büszkeség érzése, hogy nem játszanak többet „szórakoztatásra szánt” tánczenét.

B. J. Eszményítem az olyan embereket, mint Charlie Parker vagy Miles Davis, egyszerüen csodálatosnak tartom öket, úgyhogy nem arra törekszem, hogy kírjam öket a történetböl, hanem arra, hogy még több embert vonjak be a történetbe. Az észrevétlenül maradt emberek és mellözött mozgalmak, sőt teljes jazzmozgalmak egész egyszerüen eltüntek, mivel nem illeszkedtek bele ebbe a vegytiszta narratívába, érted, Louis Armstrongtól Charlie Parkerig. Számos, még ma is létező irányzatot hagytak figyelmen kívül, és persze különösen az Egyesült Államokon kívül játszott jazz kutatása mellett épp ez az, aminek a mélyebb vizsgálata igazán foglalkoztat. Érdekes megfigyelni, hogy az Egyesült Államokon belül a diaszpóra koncepciója legitimitást élvez, tehát beszélhetünk New Orleans jazzröl, Kansas City jazzröl, Chicago jazzről... itt ez egy helyénvaló különbségtétel, de amint elhagyod Amerikát, további distinkciókról vagy földrajzi különbségekröl, mozgásokról egyszerüen nem vesznek tudomást, ami számomra elfogadhatatlan.

H. Á. Az idén Gratzban megrendezett Rhythm Changes Konferencián nagy élmény volt látni a közönség érdeklödését a balti országok jazz-zenéje iránt, miután egy előadó kifejtette, hogy ezekre a sajátosan „nemzeti” jazzstílusokra hogyan hatottak a helyi népzenei és mainstream jazztradíciók. Talán mégis van valami igény a diaszporikus hangok felfedezésére és megszólaltatására...

B. J. Egyre nagyobb az érdeklődés a diaszporikus jazz iránt... az Egyesült Államokon kívüli jazzről megjelenő könyvek száma olyannyira megsokszorozódott, hogy igazán nehéz lépést tartani velük. Úgy értem, hogy a különc érdeklődésemen kívül számos más oka is van a jazzdiaszpórák vizsgálatának. Valószínűleg több jazzt játszanak az Egyesült Államokon kívül, mint az Egyesült Államokban. Bizonyára tudod, hogy számos USA-beli jazzzenész Amerikán kívül keresi a kenyerét. A nemzetközi fesztiválokból származó bevételek nagymértékben járulnak hozzá az észak-amerikai jazz-zenészek egzisztenciális fennmaradásához, ráadásul a legtöbb jazz-infrastruktúrát is a diaszpóra épitette ki. Így például a jazzoktatás nagyrészt a diaszpóra terméke, míg a jazzfesztiválok is Amerikán kívül kerültek elsőként megrendezésre: tudomásom szerint az első jazzfesztivált 1919-ben tartották Ausztráliában. 1946-tól egészen napjainkig éves rendszerességgel rendeznek jazzfesztivált Ausztráliában. A jazzfolyóiratok kiadása túlnyomórészt Amerikában kívül kezdődött; a jazzklubok is Amerikán kívül létesültek elsőként, és a jazznarratíva maga például Panassié15 tanulmánya... és persze vannak diaszporikus jazzformációk is. A free jazz jórészt Amerikán kívül alakult ki, az időközben világzenévé előlépő regionális fúziók, mint amilyen például az Afrobeat és az ECM, szintén a diaszpóra termékei... ezen jazzstílusok nagy fejlődése az Amerikán kívüli globális diaszpórán belül jött létre. Ez csupán néhány ok a sok közül, hogy valójában miért szükséges a diaszporikus jazz kutatása. Kedves volt tőled, amikor azt

15 Hugues Panassié (1912-1974) francia jazzkritikus, jazztörténész, a Hot Club de France (1932) társalapítója, majd elnöke. 
mondtad, hogy ez nagyrészt nekem köszönhető, de mostanában számos ember dolgozik ugyanezen a szakterületen. Negyven évvel ezelött még nem voltunk túl sokan, de mostanra már nagyszámú, a téma iránt elkötelezett, specializált kutatásról beszélhetünk, ami véleményem szerint nagy előrelépés.

H. Á. Mikor használtad egyértelmüen a jazzdiaszpóra fogalmát? A 2000-ben megjelenö Inaudible Music mintha a diaszporikus jazztanulmányok programadó munkája lenne, még akkor is, ha ez a könyv szándékoltan nem is használja ezt a kifejezést.

B. J. A jazzdiaszpóra fogalmát ekkortájt [az ezredforduló környékén] kezdtem el használni. Ezen a ponton sokan tiltakoztak ellene, mondván, hogy a diaszpóra kifejezés a zsidósággal kapcsolatos történelmi jelenséget ír le. Viszont a diaszpóra szó mostanában felkapottá vált és a kultúra különféle mozgalmainak leírására szolgáló általános fogalommá lépett elö. Ezt megelőzően természetesen sokat írtam a diaszporikus jazzről, mert nagyon sokat publikáltam annak ausztrál válfajáról. Szintén írtam néhány tanulmányt a finn jazzről, de ezt nem igazán neveztem még „diaszporikus jazznek”. Mindemellett nem szeretném kizárólag magamnak tulajdonítani a fogalom feltalálását, mivel különféle országokban mások is írtak ehhez hasonló jazztörténetet.

H. Á. Utolsó kérdésem az lenne, hogy véleményed szerint mennyire periferikus az ausztrál jazz és a populáris zene tudományos kutatása az angloeurópai világban? Ezt azért is kérdezem, mert nyilvánvalóan hatással volt rá az angolszász kultúra, ugyanakkor számos szempontból el is tér attól.

B. J. Számos vicces történet létezik ezzel kapcsolatban. Először is, amikor megszületett a szándék, hogy írni és publikálni szeretnék az ausztrál jazzről, az egyik probléma az volt, hogy európai vagy angol kiadóknak írjak-e. „Nem, minket Ausztrália nem érdekel” [hangzott a válasz, mikor európai lapoknál kopogtattam], amikor viszont ausztrál kiadókhoz fordultam, azt mondták: „Minket a jazz nem érdekel”. Szóval a két dolog együtt nem piacképes... Úgy gondolom, hogy az ausztrál jazz marginalizációja még mindig erőteljes az angol nyelvü jazztanulmányok akadémiai világában. Számos konferencián vettem részt, ahol közzétettem az ausztrál jazz kialakulásával kapcsolatos megfigyeléseimet, $s$ ahol néhányan jóformán azt mondták: „Nem, ez nem lehet igaz, Ausztráliában ez nem történhetett meg”. Szerintük minden Európában történik, minden fontos esemény a centrumban játszódik le. Így például a legrégebbi rendszeresen megrendezésre kerülő jazzfesztiválról, az Ausztrál Jazz Konvencióról [Australian Jazz Convention] szóló egyik tanulmány szerint csak egy feltételezés, hogy a fesztivál 1946 óta évi rendszerességgel létezik. Én erre azt mondom, nyilvánvalóan nem puszta „feltételezés”, hiszen már több mint 70 éve rendszeresen müködik... Ezt nem csak úgy „állítják” egyesek, hanem ténylegesen igaz...! [nevet]

\section{H. Á. Történelmi tény...}

B. J. Így van! Megmutathatom neked a fényképeket, a programfüzeteket, de a dologban mindig ott rejtözik egyfajta anglocentrizmus, ami megnehezíti annak elfogadását, hogy a perifé- 
rián valami különleges, valami más, valami úttörö történik. Nem vagyok biztos benne, hogy ezt bele kellene tenned az interjúba, ami egy angol folyóiratban fog megjelenni ${ }^{16} . .$. [nevet]

Fordította Tillmann Ármin

\section{Havas Ádám}

Szociológus, a Milestone Intézet Társadalomtudományi Tanszékének vezetője (Budapest).

\section{Bruce Johnson}

Kultúrakutató, a Turkui Egyetem (UTU) Kultúrtörténet Tanszékének tiszteletbeli vendégprofesszora és docense, a Glasgow-i Egyetem (University of Glasgow) Zenetudományi Tanszékének tiszteletbeli professzora, a Sydney University of Technology Kommunikációtudományi Iskolájának oktatója (adjunct professzor).

16 Az interjú eredeti, angol verziója a Jazz Research Journalnél van elbírálás alatt. 